\title{
A MODEL FOR BUILDING A RELATIONSHIP BETWEEN UNIVERSITIES AND ENTREPRENEURS
}

\author{
Santa JĀKOBSONE, Artūrs ZEPS* \\ Faculty of Engineering Economics and Management, Riga Technical University, \\ Kalnciema Street 6, Riga, Latvia \\ *E-mail: arturs.zeps@rtu.lv
}

\begin{abstract}
Purpose - the article aims to describe the main problems in cooperation between universities and entrepreneurs as well as suggestions to improve this cooperation.

Research methodology - the aim of the article has been achieved based on literature analysis, detailed content analysis of existing Latvian technical universities strategy documents and SWOT analysis, and recommendations gained through expert interviews.

Findings - one of the factors strengthening the need for cooperation is the significant shortage of engineering and ICT specialists in the coming years; therefore, authors have analysed technical universities strategy documents. The article suggests that improvement in the cooperation can be reached if academic institutions would apply a unified system for better cooperation with industry.

Practical implications - the model, which is described by authors as the SADI model, provides an opportunity to strengthen cooperation with industry taking into account such factors as availability of the resources; university's strategic aims, the intensity of communication with entrepreneurs and others. The model provides support to the management of the university in planning cooperation and developing appropriate structures to support it. It as well it can help university's management to structure cooperation activities, thus strengthening it and generating additional resources.
\end{abstract}

Originality/Value - authors have not found such a detailed model in advance so that it can be considered a novelty.

Keywords: cooperation model, strategy, university-industry.

JEL Classification: I2, L3, M5.

Conference topic: Contemporary Organisations Development Management.

\section{Introduction}

Workforce disproportion is an increasing problem in Latvia. By the year 2022, in Latvia there will be around 10000 surpluses of humanitarian and social science specialists and the shortage of around 16000 science, engineering and information and communication technology (ICT) specialists, says report made by Latvian Ministry of Economics. (Ekonomikas ministrija, 2016). Quality and range of offers made by university play a significant role in solving this problem. Improving quality comes with a financial cost, which not always can be covered by the university itself; therefore an essential step in universities development is to attract both financial and non-financial support from entrepreneurs. Another critical aspect is the influence of higher education on national economies. Contribution to national economics is made by study process, where specialists are being prepared, who will later become taxpayers and business owners. Also, these specialists will bring the country's name in the world with their research and valorisation activities, which will allow both public and private structures to introduce innovations and new products (Zeps, 2016). Great Britain, the United States of America and other country universities are calculating their influence on national economics and, for example, Great Britain has calculated that their universities in the period between years 2010-2011 has contributed 3,3 billion pounds to national economics (Northam, 2012). This contribution is made by business consultations, commercialisation of new technologies, training and consulting in various problems and other services which can be done by university teaching staff and researchers.

Summarising all above, it can be seen that the relationship between universities and entrepreneurs is essential not only for universities, which will gain additional financial support for development and attracting specialists to study process, but also for entrepreneurs, who will gain qualified workforce that helps them become more competitive, but 
also to national economies (Mascarenhas, Ferreira, \& Marques, 2018). Previous research in Spain, France and Portugal shows, that from 375 entrepreneurs who have made interest in cooperation with universities, only 10\% ended up cooperating with them (Fernández-López, Calvo, \& Rodeiro-Pazos, 2019). Looking at Latvia, all possible cooperation directions are not defined together. Also in project "Research of alternative models for improving study process and industry cooperation," one of the conclusions is that there is lack of systematical approach on how to cooperate with entrepreneurs, and one of the possible solutions is to create unified model and methods for cooperation between universities and entrepreneurs (Dubickis et al., 2017).

\section{Barriers in cooperation between industry and universities}

Comparing world practice in industry and universities cooperation and Latvian technical universities and industry cooperation, activities that have been implemented are similar, and almost all of them have been realised in Latvia too, however many of them - in the smaller scale. For example, cooperation in research, entrepreneurship universities, including academic entrepreneurship, entrepreneurship universities and creating technology-based businesses (business incubators, free entrance to start-up developing etc.), human recourses transfer (mentors from entrepreneurship, common business problem solving, internships where students can work together with professionals and improve their academic knowledge practically etc.), industry advisory committees, informal interaction, financial support (Bikse, Lusena-Ezera, Rivza, \& Volkova, 2016; Stal, Andreassi, \& Fujino, 2016; Mascarenhas, Marques, Galvão, \& Santos, 2017; Nielsen \& Cappalen, 2014; Perkmann \& Walsh, 2007). Based on information founded through literature analysis and in world largest universities websites, especially in the US, for example, graduate organisations are very popular, and it should be considered as a strategically important asset in university management (Martin, Moriuchi, Smith, Moeder, \& Nichols, 2015). Participants of these organisations are often middle, or senior managers of large companies, that can provide both financial and human recourses support to universities. Moreover, graduate's support has been obtained not only from companies, but also form individuals that are not so popular in Latvia, and it has been measured in more than $25 \%$ of total amount of donation for universities development activities (data of the year 2017).

In world examples, universities cooperation with entrepreneurs in research is also widespread, and in most of the cases that has been turned through awareness of opportunities offered by universities, graduates that know what their universities can offer to their companies' development and availability of information.

Table 1. The most significant barriers in industry and universities cooperation un Latvia (source: Dubickis et al., 2017)

\begin{tabular}{|l|l|}
\hline \multicolumn{1}{|c|}{ Barrier } & \multicolumn{1}{c|}{ Explanation } \\
\hline Lack of resources, especially in companies & $\begin{array}{l}\text { Companies point to lack of resources, including human, time and } \\
\text { money resources (least mentioned lack of money resources) }\end{array}$ \\
\hline Communication problems & $\begin{array}{l}\text { Companies point to lack of information about cooperation opportuni- } \\
\text { ties with universities }\end{array}$ \\
\hline $\begin{array}{l}\text { Low interest and motivation of universities } \\
\text { personnel }\end{array}$ & $\begin{array}{l}\text { University personnel - students, professors, scientific and academic } \\
\text { personnel }\end{array}$ \\
\hline $\begin{array}{l}\text { Lack of competencies and/or infrastructure in } \\
\text { the university }\end{array}$ & $\begin{array}{l}\text { Universities do not have the necessary competencies to solve prob- } \\
\text { lems of companies, students do not have the necessary knowledge, } \\
\text { so there is low reliability of result quality }\end{array}$ \\
\hline Lack of interest and motivation to cooperation & For both sides \\
\hline Confusion about intellectual property ownership & Particularly relevant to companies \\
\hline $\begin{array}{l}\text { High bureaucracy, difficult cooperation organis- } \\
\text { ational process }\end{array}$ & Project development process is too slow \\
\hline $\begin{array}{l}\text { Unified structure for cooperation coordination, } \\
\text { no methodology for project development }\end{array}$ & Lack of support units in universities \\
\hline
\end{tabular}

Graduate's organisations in Latvia have not been very responsive, and most often this can be explained by the lack of sense of belonging to university both during the study process and after graduation.

It can be explained by a relatively short time that students spent in university. Most of them start working very early due to insufficient financial resources, devoting less and less time to studies, not mention engaging in university social life.

A particularly crucial hindering factor in industry and universities cooperation is the lack of communication, which can be observed both in the opinions expressed by various authors in the world practice and the recent study on the situation in Latvia "Research of alternative models of the study process and industry cooperation measures" (Kozlinska, 2012). Moreover, it is vital for both sides to perceive each other as an equal partner for better results (Rasmussen \& Wright, 2015). Most significant barriers in industry and universities cooperation founded in this research are defined in Table 1. 
Resource shortages can be solved by initially putting at least one representative in the universities responsible for cooperation with industry. The appointment of such a person could shorten the time that companies spent to find the right contacts in each university. Promoting the motivation of university staff and company employees for cooperation is a question that should be dealt with at the management level of each party, as it is directly dependent on the benefits that such cooperation could bring. The problem that needs to be tackled through cooperation is the lack of competencies and infrastructure for universities, as both sides can provide a great deal if they work together - entrepreneurs can provide financial and material support for infrastructure renewal, as well as the retraining of the academic and researcher skills. While academics can provide academic innovations. In addition to students' knowledge, the work should also be invested by companies, not just universities, and this should be done within the study process, as companies need trained specialists. High bureaucracy and a complicated process of cooperation could be solved with the introduction of a unified structure and a cooperative model to follow. Summarising the barriers mentioned above to cooperation, the authors concluded that most of them should be solved by developing a unified model of cooperation that would provide the university with guidelines on how to build long-term relationships with entrepreneurs, implement activities to promote cooperation and more easily qualify for financial support if it is necessary.

\section{Research methods}

The first analysis of literature was done, after that, the authors examined development strategies of Latvian higher technical universities, SWOT analyses carried out by universities and their content analysis, defined questions and conducted interviews with experts. From the content analysis and recommendations from experts, the authors have created a model for developing relations between universities and entrepreneurs (see Figure 1).

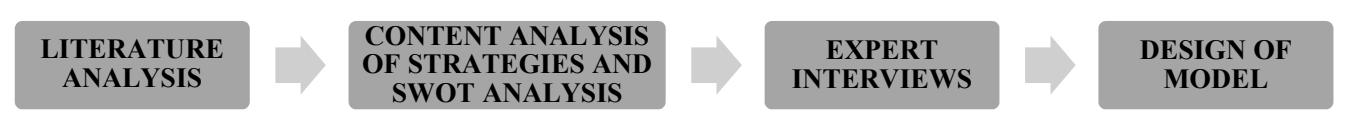

Figure 1. Research methods (source: created by authors)

In his doctoral thesis "Strategic Solutions for Sustainable Development and International Excellence of Organizations" A. Zeps (2016) points out that the development of strategies for universities differs significantly from their development in business organisations. The main difference is their goal - profit-making is the main goal of business organisations, whereas in most cases it is not primary for universities - strategies are created to ensure international excellence and sustainable development. Similarly, to the early stages of business organisation strategy development, it is also important for a university to define different characteristics compared to competitors, which in this case are other universities (Caune \& Dezdons, 2009; Zeps, 2016). Based on the defined distinctive features, universities can determine a strategic direction that is particularly important during the future implementation of the strategy. The authors have studied the websites of Latvian technical universities and found publicly available development strategies. The directions, goals and activities of each university for the achievement of those involving entrepreneurs and industry are distinguished and grouped from their strategies, thus enabling to conclude what kind of cooperation is the most significant for them. Mostly the strategies include some five-year plans, and also most important development directions are mentioned.

In order to assess the extent to which these universities achieve their goals, their strengths and opportunities for development, as well as weaknesses and threats, the authors have also compiled publicly available SWOT analyses in which they conducted their self-assessment. From these SWOT analyses, the authors have identified and grouped activities or statements involving entrepreneurs and industry.

After compiling and grouping the data, the authors have carried out a qualitative analysis of the development directions defined in the strategies of all nine Latvian technical universities of higher education and the goals set in them, as well as strengths, weaknesses, opportunities and threats identified in the SWOT analysis which involve entrepreneurs. Qualitative content analysis is a research method for subjective interpretation of text content using systematic classification (Hsieh \& Shannon, 2005). This method has been chosen because it provides an opportunity to identify the most common trends - most frequently seen directions and goals set in strategy, thus concluding which of those are most important soon for Latvian technical universities at the national level. The analysis of SWOT analysis data with the involvement of entrepreneurs reflects the prevailing trends in the real situation in Latvia, which allows determining the extent to which the goals set in the strategies of the higher education institutions are achieved, and which creates the most significant problems directly at the national level.

Expert interviews are one of the qualitative research methods that provide a broader understanding of the situation, different attitudes and provide a specific and professional understanding of the research topic (Sabiedriskās domas un tirgus izpētes centrs, 2012). The authors have selected individual interviews done through telephone asking predefined questions and also questions that came up during the conversation. This type of interviews was chosen to save both the interviewers and authors' time spent in a compartment with a face-to-face meeting and also low costs of such 
actions. Interviews were conducted at various times previously agreed with experts and each interview lasted about 25-55 minutes.

As experts, two representatives from the management of engineering companies, two representatives from the management of technical universities, as well as the vice-rector of development of the largest technical university in Latvia were selected.

The areas of the selected companies are not only among the engineering top 10 most demanded study programs in the country in 2016 and 2017 but also in terms of employment after graduation and even during studies - construction, information technology and computer science (Latvijas sabiedriskie mēdiji, 2017; Ozols, 2018).

In total, nine questions have been defined for expert interviews in order to clarify the views of experts on cooperation between existing universities and entrepreneurs and to listen to expert advice for improvement. The questions were selected based on the main problems revealed in the first part of the research in cooperation between universities and companies both in world examples from different literature reviews and based on studies conducted in Latvia.

\section{Results of the content analysis of strategic lines and goals and SWOT analyses of technical higher education institutions in Latvia}

The results of the content analysis revealed that the main strategic lines of technical higher education institutions in Latvia are studying process and outstanding results in science and research (mentioned 7 times), followed by cooperation with the interested parties (mentioned 4 times), among which are mainly entrepreneurs and industry representatives. As the most important strategic goals, technical higher education institutions in Latvia have pointed out joint project execution with entrepreneurs and ensuring accessibility of infrastructure (mentioned 18 times), study program update to the current employment market requirements (mentioned 11 times) and improving cooperation with entrepreneurs (mentioned 11 times). Besides, not less important goals are involving entrepreneurs in the study process and developing the application of knowledge and technologies to business (these goals are mentioned 8 times). Considering the more or less similar number of mentioning other strategic goals (mentioned 6 and 7 times), the strategies of higher education institutions drive to a conclusion that they generally have similar goals.

Investigating the strongest points defined in SWOT (Strengths, Weaknesses, Opportunities and Threats) analyses of technical higher education institutions in Latvia, fruitful cooperation with entrepreneurs, characterised by improvement of study programs, and employment after completing studies are the most frequently mentioned. Although successful cooperation with entrepreneurs is mentioned as the most important strong point, higher education institutions have pointed out weak or insufficiently developed cooperation with entrepreneurs. This causes a certain contradiction on the one hand, this cooperation is considered to be successfully carried out, on the other hand, universities recognize that much of the capacity remains unused - cooperation is not adequately contemplated and structured, and not all opportunities that may be much of a gain for both sides are used. In the meantime, insufficient financial resources are mentioned as a weak point of higher education institutions (mentioned 4 times), which ultimately can be solved by entrepreneurs' support. SWOT analyses of universities most frequently mention the shortage of high-level specialists, observed in Latvia, as a weak point; however, this is a common issue on the state, business and educational level. Shortage of specialists, by all means, allows universities to claim additional attention and financing from the state for enhancing study programs, however, at the same time must think about those who have already begun their studies and continue them at the programs that have not been upgraded for a long time. Education institutions should be able to get students interested and maintain their attention as well as to promote practical qualification, and for this purpose, entrepreneurs' support is particularly important. As a threat, higher education institutions most frequently mention inadequate financial support from the state and inability to gain it from entrepreneurs. Taking into account that education institutions cannot influence the allocation of the state financing, unless they are able to meet specific requirements, which partly can be also caused by shortage of finances (for instance, a high number of publications of PhD students in prominent scientific journals is pointed out as an achievable result, but support for doctorate scholarships is not granted, or it is very little, for this reason, it is difficult to achieve such a goal and the like), universities shall work on gaining more extensive support from entrepreneurs of particular branches of economy. This can be achieved by systematic and thorough work on forming contacts and cooperation in various ways.

\section{Experts' interview results}

Experts' opinion in most cases has been similar; for this reason, authors have summarised the most important conclusions that were useful for elaborating a cooperation model.

\subsection{Cooperation activities}

Virtually all experts have pointed out that entrepreneurs should cooperate with universities and provide various forms of support, i.e. consulting, human resources and, within reasonable possibilities, also financial support. 
The most common type of cooperation between higher education institutions and business, according to the experts' opinion, is providing internship for university students. One of the experts stated that over the recent years, enrolment competition for scholarships for promoting practical skills, arranged by universities' funds in cooperation with different Latvian companies, has become quite demanded both by entrepreneurs and students. The advantage of such competitions comparing to providing a place for an internship in a conventional manner is, first of all, a competition procedure, meaning that an enterprise gets the best student, not just the first applicant. Secondly, during such an internship an enterprise, cooperating with a correspondent fund, can pay scholarship that is not levied by taxes to a student. Otherwise, companies often decide to pay for an internship, concluding an employment agreement, which causes higher financial expenses to the enterprise. Thirdly, the enterprise is partly freed from the administrative burden - the fund performs the first selection of applicants and preparation of all relevant documents. Finally, as a result of such a competition, the enterprise gets to know the student, and in some cases, already after the end of the internship, they agree on constant collaboration, concluding an employment agreement, and the enterprise gains a more knowledgeable employee who is already familiar with the company.

Besides, the experts point out providing support for various purposes as a widely accepted type of cooperation. Starting from granting scholarships mainly to students of those areas, in which the enterprise conducts its business, and financial support for various student projects, up to more extensive support for equipping labs and carrying out new initiatives.

\subsection{Entrepreneurs' involvement in the study process and improving the qualification of employees}

Entrepreneurs' involvement in the study process is common in Latvia as they may be invited as guest lecturers within the study courses or participate in students' diploma paper evaluation boards, they may also suggest solving problems topical for a certain enterprise to students in their diploma papers, proposing themes for diploma papers and offering help of their representatives in elaborating the diploma work. Some experts also state that entrepreneurs get involved in improving study programs to upgrade their conformity to the market requirements. One of the experts has also shared negative experience - the enterprise represented by this expert elaborated suggestions concerning what should be improved and what changes should be introduced to some of the study programs to make them more fit for the actual employment environment, however, the university's reply was that it did not dispose of adequate teaching personnel for introducing these changes, and for this reason, the suggested changes will not be implemented. As the expert admits, entrepreneurs would be more motivated to get involved in the study process by more pro-active actions by the universities themselves since quite often the universities are not ready for changes.

One of the experts refers to improving the qualification of the employees of the group of enterprises he represents and other Latvian enterprises in cooperation with universities as to one more type of cooperation. As they elaborate the study contents together, the enterprises and the universities compose individual courses of lectures in order to improve the knowledge of their current employees, making them better fit for the market requirements. As the expert recognises, such qualification improvement sometimes is performed not only for the companies' employees but also for university tutors who attend enterprises to acquire the current updates in a specific area so that they are further able to give this knowledge to their students.

\subsection{Cooperation in research}

Besides, especially, in the IT area, contract researches and contract works that entrepreneurs assign to university researchers are common. One of the experts refers to foreign experience as to the unused potential for developing such a type of cooperation. Entrepreneurs commission solving not a topical problem to a university, opting for one of the solutions - if funds are adequate, and the results are needed urgently, they assign this problem solution to university researches as a contract work or a contract research, if the enterprise does not have an opportunity to invest a significant amount for solving this problem and the results may be received within up to 6-month period, then this problem may be assigned to a last-year student or a group of students who work on the problem under the tutors' supervision. In this case, the company pays the students, and the tutors only provided that the problem solution is found and the work is well performed. There are different variations of such a cooperation model, but it is undoubtedly valuable for both sides.

\subsection{The most important cooperation in manners}

Regarding the question, which of the said manners of cooperation between universities and businesses are particularly important in development of higher education and preparing specialists in specific areas, all experts replied that all types of cooperation are important, however, of particular importance is providing places of internship and practical training to students already during their studies. One of the experts stated that professional study programs should be made more sustainable - it should be known what entrepreneurs expect from the universities in the short term and the long term, what knowledge should be acquired before the first internship, what should be learnt already at the university and what should be left for professionals at the enterprises, etc. To make the study process more comprehensive and interesting, the experts also point out the financial support of enterprises as a significant factor. Unfortunately, at the 
moment, most of the universities are not able to provide modern and well-equipped labs and classes at their own expense, and this is achieved only with the support of entrepreneurs who donate to universities' funds, which is suitable for entrepreneurs. As one of the experts stated, a possibility to provide financial support in the form of a donation is often one of the most important factors in granting financial support. Likewise, all experts recognised that scholarships sponsored by enterprises and other motivating activities for students considerably improve the students' efforts not only in acquiring the study courses but also in completing them better.

\subsection{Evaluation of current communication}

As concerns communication and information on the universities' websites, the experts' opinions differ. A construction company representative has been the most optimistic as he believes that information is adequate and further information may be obtained by contacting the universities' communication officers. The university's representative recognised that information might be obtained by using personal knowledge and contacts whereas websites of universities do not provide sufficient information and many enterprises do not even know what universities can offer. Other experts argued that information is insufficient, and its shortage often is the cause of lack of cooperation in a particular area - entrepreneurs are often unaware of the universities' offers. An IT company representative during the interview referred to an example from Cambridge University, which suggests that enterprises conduct researches for solving topical problems and regularly publish the most successful examples of cooperation on their websites, and she was surprised that higher education institutions in Latvia could also offer something similar (the authors' remark - not informed).

Regarding the question what information, according to the experts' opinion, should be published on universities' websites, all experts agreed that all possible types of cooperation and their descriptions, as well as contact persons that may be contacted in case of questions, should be made available. According to the experts, every university should give particular attention to their competitive features that differentiate them among other universities and colleges. From the entrepreneurs' point of view, it would be very convenient if all descriptions of study programs as well as their schedules - what the students acquire during each semester, when study internships are scheduled, how many days a week students have lectures and other relevant information were available on one website, which would help to find new employees and help to navigate through the wide offer of study programs. As concerns researches and infrastructure, experts indicate that entrepreneurs often are interested in available infrastructure and equipment that may be used for their own needs - at the moment, for instance, Riga Technical University has such scientific infrastructure lists; however, they could be published in a format more accessible for entrepreneurs. The problem and the reason why works of universities' researchers often do not reach the target audience - entrepreneurs are even unaware of them, in experts' opinion, is in insufficient sharing good examples with wider society. Experts believe that in universities there must be someone in charge of cooperation with industries who should preferably be educated in communication and who would regularly inform society on the university's performance, would create and maintain an attractive website and encourage discussions among the industry specialists as well as would participate in exhibitions in Latvia and in international exhibitions, searching for new cooperation partners and offering services offered by the university in the broader scale. A university representative mentions insufficient human resources as a problem of educational institutions since quite often the tutor, the head of the program, the head of the institute, the researcher and also an administrative worker are confined in one person who unfortunately does not have time to participate in exhibitions and other activities enabling him or her to communicate about his or her field to a broader society while this is very important for recognition and development.

\subsection{Recommendations to improve communication}

Almost all experts have indicated that mutual communication can undoubtedly be improved by the availability of a unified platform in each university, which would enable finding relevant information on manners of cooperation. One of the experts points out another problem in the current communication, which is particularly common in larger educational institutions of Latvia. These institutions consist of several faculties, each of them having students' self-governing bodies, sometimes also a fund and a career centre while each of these bodies requests support from enterprises at different times, each has its conditions, and as a result the enterprise has to communicate with several representatives from the same university; besides, they are not always informed on previous successful or not so successful cooperation. During the recent years, several enterprises have required from an educational institution to prepare a list of planned activities and projects for a year, summarising therein all activities of the universities' structural units, and expressed a wish to consider a possibility of supporting once a year. Such a process certainly obliges the university to plan its activities timelier, but it considerably facilitates the enterprise's work in providing support as well as creates assuredness of the necessity of the investment provided by the enterprise.

Among factors that motivate entrepreneurs to cooperate with universities, experts have mentioned the university's reputation and ability to prepare highly qualified specialists who become employed by the enterprises whereas for universities this presents an opportunity to improve the available study programs, ensuring the university's prestige and quality of education as well as a possibility to gain additional financing. 
According to the experts, universities' structural units should be responsible for cooperation with entrepreneurs as the former can present the offered possibilities and pro-actively react to the industries' wish to cooperate. Experts believe that the largest universities should appoint one person in charge on the university's government level, not only in structural units as this person can represent the educational institution in a wider scale and regularly take care of engaging new partners and maintaining the university's image in general society. The IT representative indicated that it would be convenient for enterprises if information about the person in charge of these duties were provided on the website, along with the sphere of competence of every person in charge (whether this person is entitled to take decisions and other similar information).

In the experts' opinion, the main conditions that universities and colleges should observe to make enterprises decide to provide financial support to them, first of all, is gaining business confidence by preparing highly qualified specialists. Good qualification of specialists whom an enterprise gains from the respective university are the main rate of the latter's performance and causes assuredness or, on the contrary, doubts as to whether to provide financial support. It is also vital for the university to be ready not only to spend the allotted support but also to take the initiative for new cooperation opportunities and to react pro-actively to the ideas offered by enterprises. According to experts, it is essential to be aware of the common goal and to work on its achievement together, not only to expect its benefit from cooperation.

\section{Model of building cooperation between universities and enterprises}

At the end of the 20th century, Etzkowitz and Leydesdorff formed the Triple Helix Concept, that is the concept of relations between universities, businesses and government (Stanford University, n.d.). It describes the role of each party, focusing on the development of innovations and economic potential in cooperation, not only on a specific activity, which is to be performed by each of the parties. The authors suggest a model, which they have called SADI (Setting strategic priorities; Analysis of activities and promotion of responsible persons; Defining "to do" activities model; Implementation and monitoring activities), which defines building relations with businesses by universities and colleges (see Figure 2).

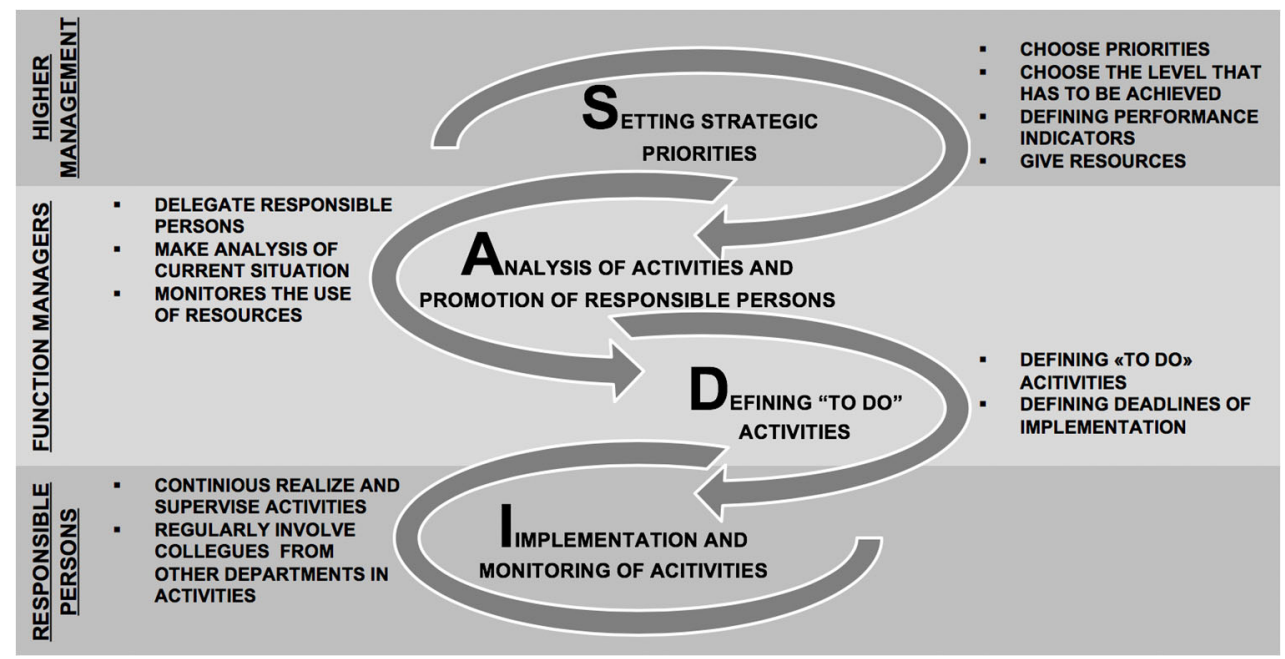

Figure 2. SADI model for building a relationship between universities and entrepreneurs (source: created by authors)

\subsection{Defining strategic priorities}

The first step in using this model should be choosing strategically important priorities in cooperation with entrepreneurs by the university's highest administration. Defining available resources and selecting ones suitable for promoting cooperation is of no lesser importance. The next step is defining the desired results to be achieved that the authors propose on three levels (Table 2).

Within the necessary level of relations, an enterprise concludes a general cooperation agreement with a university. Referring to such an agreement can make the further cooperation process, and the enterprise highest management will not need to review the performance or support of the joint projects. If necessary, the university contacts the enterprise with a request to support an individual project or activity whereas the enterprise contacts the university when it needs its services - arranging personnel training, performing contract research or contract work, and the like. On the basic level, cooperation is mostly one-way, and the winner is mostly one party (see Table 3) whereas the other party's involvement is rather minimal. 
Table 2. Levels of the model of building relations between education institutions and entrepreneurs and achievable results in each of them (source: created by authors)

\begin{tabular}{|c|l|}
\hline Type of model & \multicolumn{1}{|c|}{ Achievable results } \\
\hline Basic level & $\begin{array}{l}\text { Comprehensive cooperation agreement, periodic, irregular receiving of support for college projects and } \\
\text { providing various services to business. }\end{array}$ \\
\hline Medium level & $\begin{array}{l}\text { Building enhanced structured cooperation, facilitating communication of entrepreneurs with education } \\
\text { institutions and offering broader cooperation possibilities and gains from them. }\end{array}$ \\
\hline Higher level & $\begin{array}{l}\text { Forming enhanced, structured relations for achieving equal involvement of both sides and co-working } \\
\text { in achieving the common goals. }\end{array}$ \\
\hline
\end{tabular}

Medium level relations involve more enhanced and structured cooperation on the university's side, which makes communication in addition to that more accessible for enterprises and offers broader possibilities of cooperation, from which both parties' benefit. Besides the activities included in the basic cooperation level such as concluding a general cooperation agreement, financial support for the university and providing services to businesses, on this level of cooperation the university carries out two essential activities for improving the communication process - forming a database enabling any university representative to know about the current communication with the respective company and to make comments as well as creating a platform on the website for topic exchange, proposing discussions, etc. To make providing support more accessible and more convenient for enterprises, on this level the university establishes a fund, granting it a social benefit status, and if possible, affords to pay scholarships to students. Already on the basic level, the universities also involve students in providing services to enterprises in order to introduce students who are the most active in the respective areas and to give students a better understanding of the industry problems and updates.

Table 3. Levels and activities of a model for building a relationship between universities and entrepreneurs (source: created by authors)

\begin{tabular}{|c|c|c|c|c|c|c|c|c|c|c|c|}
\hline & & \multicolumn{10}{|c|}{ Activity } \\
\hline $\begin{array}{l}\text { Type of } \\
\text { model }\end{array}$ & $\begin{array}{l}\text { The winner of } \\
\text { the relationship } \\
\text { (U-university, } \\
\text { E-entrepreneur, } \\
\text { S-society) }\end{array}$ & 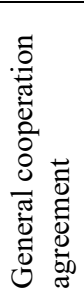 & 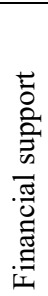 & $\begin{array}{l}0 \\
0 \\
0 \\
0 \\
0 \\
0 \\
0 \\
0 \\
00 \\
0 \\
0 \\
0 \\
0 \\
0 \\
0 \\
0 \\
0 \\
0 \\
0\end{array}$ & 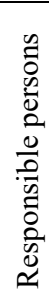 & 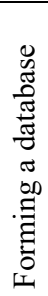 & 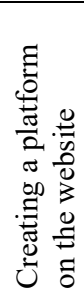 & 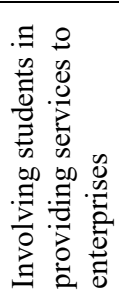 & 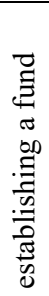 & 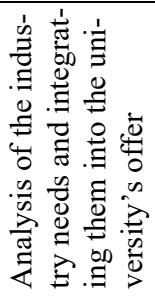 & 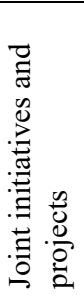 \\
\hline Basic level & $\mathrm{E} \rightarrow \mathrm{U}, \mathrm{U} \rightarrow \mathrm{E}$ & & & & & & & & & & \\
\hline $\begin{array}{l}\text { Medium } \\
\text { level }\end{array}$ & $\begin{array}{c}\mathrm{E} \rightarrow \mathrm{U}, \mathrm{U} \rightarrow \mathrm{E}, \\
\mathrm{U} \leftrightarrow \mathrm{E}\end{array}$ & & & & & & & & & & \\
\hline Higher level & $\mathrm{U} \leftrightarrow \mathrm{E}, \mathrm{U}+\mathrm{E} \rightarrow \mathrm{S}$ & & & & & & & & & & \\
\hline
\end{tabular}

The higher level of building relations, besides the aforementioned things, involves only activities to be performed by both parties together, from which not only the respective parties, but also general society benefits - analysis of the industry needs and integrating them into the university's offer, which would be beneficial not only for the respective enterprise, but to the industry in general and also to the university students who will have a possibility to acquire education matching the employment market requirements, it also involves carrying out joint initiatives and projects.

\subsection{Analysis of activities and appointing officers in charge}

The next step already is within the competence of the university's functional administrators. Functional administrators should appoint the responsible officers who will carry out the activities. Functional administrators should also define, which of the activities specified in the model are already being carried out, how often and to what extent. It should be defined on which level the university currently is and what it lacks to achieve it to the full measure. Functional administrators should also define how many resources improvement of each activity will take.

\subsection{Setting forth activities to be carried out}

The competence of the university functional administrators also involves defining activities that should be carried out and timing of performing these activities for the responsible employees, based on the activities defined on the previous stage, which have already been performed and need to be improved and the ones that should be implemented from the beginning. This timing should be set according to the rates of performance established by the highest administration. 
For instance, RTU highest administration can set as an achievable goal forming a reviewable database with all agreements, concluded with entrepreneurs, and the contents thereof within half a year. The functional administrators can appoint the employees who will be responsible for processing information.

\subsection{Implementation and supervision of activities}

Every university that decides to form relations with entrepreneurs according to this model, depending on the possible level set by the highest administration, can choose to what extent every activity mentioned in Table 4 in the appendix can be carried out. The decision is taken concidering the available resources and possibilities. Further, each section or activity to be implemented is described in more details.

\section{Concluding cooperation agreement}

The university concludes with new partners general cooperation agreements defining the rights and the duties of each party and specifying possible areas of cooperation:

- regular and systematic involvement of the entrepreneur's representatives in the university study process, which can be:

- guest lectures on the themes known by specialists in the course of study process and teaching some study courses;

- participation in improving study programs, proposing areas that need to be improved and solutions, including specific themes;

- visits to enterprises within and outside the study course;

- offering diploma paper themes for solving by the last-year students;

- participation of the enterprise representatives in diploma papers evaluation boards;

- regular and systematic providing places of internship to students during obligatory study internship and qualification internships, also to the interested persons who wish to take internships on their own during the time free from lectures;

- granting scholarships to the best students in the area, thus motivating students to higher achievements;

- granting financial and property support to university projects within the possibilities;

- cooperation in research, working on solving problems topical for the area, improving the process efficiency, etc.;

- enterprise priority rights to the knowledge generated by the university and technologies in a specific area, etc.;

- rights of using the university infrastructure;

- possibilities of using the premises of the enterprise and the university;

- participation of the enterprise representative in the convention of counsellors, commenting on the decisions and proposals of the administration, giving advice for more efficient work of the university;

- involvement of the enterprise employees who have graduated the relevant university in the association of the university alumni, offering them respective discounts for attending the university activities, for the services provided by the university, etc.

\section{Raising funds}

Irregular and periodic provision of financial support by enterprises to the university for carrying out various activities and projects, which are usually conducted by the concluded advertisement, sponsoring and other agreements, prepared by separate structural units or students' organisations. Support is requested from time to time, and sometimes it is necessary within a rather short term, which does not guarantee that the enterprise will provide it timely, even if the financing is available since preparation and negotiation of documents sometimes takes time.

\section{Providing services}

Providing services by a university to entrepreneurs, which by nature is not cooperation, but a unilateral service for payment. Universities can offer various contract researches and contract works to enterprises within the competence of the universities, arrange courses for enterprise employees, offer premises for rent for the enterprise needs, arrange conferences or post announcements of the enterprise.

\section{Appointing the persons (groups of persons) in charge}

The university administration appoints one full-time employee in charge of maintaining relations and cooperation with entrepreneurs. This person should possess knowledge of communication and marketing to be able to elaborate reviewable, attractive cooperation offers to businesses as well as to professionally communicate these offers to entrepreneurs. This person should be also pro-active and possess excellent communication skills, be proficient in languages in order to be able to communicate both with the domestic and international entrepreneurs and prospective partners, to 
participate in various technical exhibitions, conferences and seminars, to present the university's achievements, topical projects, to share examples of good practice, etc. This person should also know the structure of the university, the competence and the possibilities of each structural unit in order to get the entrepreneur and the contact person representing the university together in case of specific questions and to continue negotiations on a more detailed level.

Besides the chief person in charge of cooperation with entrepreneurs, the responsible persons in charge of a particular field from each structural unit and faculty of the university should be appointed. The number of these persons depends on the size of the university and the number of its structural units that can offer cooperation possibilities to entrepreneurs.

\section{Creating a database}

The responsible person together with the rest of the representatives of structural units creates a database administering all activities and communication with entrepreneurs. A similar example in the business environment is the model Customer Relationship Management, however, in the case of the university the direct purpose of the database is not selling, but maintaining a relationship. The main sections that should be included in such a database are as follows:

- Information on cooperation agreements with entrepreneurs concluded and valid by the moment of creating the database and information on:

- cooperation lines defined therein;

- current communication and cooperation activities (and their results) and the persons in charge of these duties - contact persons from the university;

- contact persons from the enterprise;

- enterprise budget planning schedule if available, enabling to request support at the right moment in case financial support is needed.

- Information acquired and summarised from each structural unit of the university on the enterprise, with which:

- any cooperation has been over the recent years (what specifically and what the results were);

- unsuccessful cooperation has been over recent years (reasons why).

- Information acquired and summarised from each structural unit of the university on enterprises that are included in the list of desirable partners, but for some reason have not yet been contacted.

\section{Creating a platform}

The university places a separate platform or section "For Entrepreneurs" in a place that is easy to see, in which:

- information on the university is available, and its competence features - what makes it different from other schools are particularly highlighted;

- descriptions of the offered study programs, including information on the time schedule - information on subjects that students acquire each semester, information about internships time and length, approximate amount of lectures during each of the courses, are available, enabling the entrepreneur as a prospective employer to plan and to contact particular students of particular study programs and to be informed on what they already have acquired and how much time should be devoted to work or internship;

- all possibilities of cooperation with enterprises offered by the university (in research, study process, topical projects, for which support is needed, accessible infrastructure, etc.) are described;

- contacts for each of the possibilities mentioned in the previous clause are specified, ensuring the possibility of immediate contacting the responsible person when necessary;

- for each of the possibilities mentioned above of cooperation, good examples or examples of cooperation performed with others by the present moment are mentioned;

- discussions on topical themes of the industry are regularly proposed, success stories are published, entrepreneurs are informed on the newest researches, discoveries, etc.

It is essential that the created platform should be regularly updated, supplemented by new information, success stories, project analyses, reports, usage of finances received by the moment, etc.

\section{Creating a fund}

The university creates a fund with a social benefit status for promoting the university development that can administer receiving donations from entrepreneurs, making provision of financing less costly and more convenient. Majority of higher education institutions in Latvia are state budget institutions where the process of purchase of things necessary for carrying out projects is prolonged. To make the performance of different projects less time-consuming, usage of donations received by funds does not have limitations, which means that project performers - responsible representatives of the universities can purchase services and goods faster, and thus save time, which would be necessary for negotiations. The fund can also acquire rights to pay scholarships to students and academic personnel, which is an 
attractive manner of cooperation for entrepreneurs. Various motivating competitions for scholarships and awards provide an opportunity for an enterprise to direct this support as a donation as well as to make the company is known among students - prospective employees.

\section{Analysis of industry needs and its integration into the offer}

Taking into account rapid technology advancement, more and more companies need specialists possessing interdisciplinary knowledge such as a business analyst with IT knowledge or an entrepreneur with excellent analytic skills and high creative skills at the same time. This is an activity where both employers - entrepreneurs and higher education institutions should get involved in, and from this, not only the involved party but society in general, including other businesses and current and prospective students benefit.

The university analyses the needs of the industry and the needed skills and qualifications of prospective employees and enhances the current study programs, creates new programs, interdisciplinary programs, etc., to ensure preparing specialists meeting the market requirements. Taking into account the estimated excess of specialists in humanities in the near years, it is topical to create programs for the possibility of re-qualification of the current students as well as those students who have already graduated these disciplines to ensure a possibility to replenish this knowledge in order to successfully work in the areas where shortage of specialists is more pronounced, particularly in engineering science, and to prevent the acquired knowledge from becoming unused.

\section{Joint initiatives and projects}

For solving problems topical for the industry, universities together with entrepreneurs set forth new initiatives nationwide, elaborate joint projects, programs, etc. Such projects can be competitions and projects for motivating the current and prospective students and joint opinion articles in media, recommendations to management for solving industry problems, etc. In this activity, generating joint ideas and solutions is also very important.

\section{Further research}

For further research, authors suggest creating a formula for financial calculations to determine possible SADI model level. The formula should include indicators such available financial resources, human resources (working hours, average salary level in country etc.), amount of additional resources etc. Such calculations would allow higher management of universities to understand their opportunities better and plan a budget.

\section{Conclusions}

According to the authors' literature analysis, the main problem in cooperation between entrepreneurs and universities is the lack of communication. The most significant development directions mentioned in the strategies of Latvian technical universities concern the study process, excellence in science and research, as well as cooperation with interested parties, among which are industry representatives and entrepreneurs. The most frequently mentioned goals in university strategies are the implementation of joint projects with entrepreneurs, maintaining access of infrastructure, adaptation of study programs to current labour market requirements, as well as improvement of cooperation with entrepreneurs. The most frequently defined strengths in SWOT analyses of technical universities in Latvia are the successful cooperation with entrepreneurs, which is manifested both in the improvement of study programs and employment after graduation, and also advanced and modern infrastructure, but from the other side, most frequently mentioned weaknesses are poorly and not fully developed cooperation with entrepreneurs, and also poorly developed infrastructure, which in turn shows untapped potential in these directions. Most frequently mentioned development opportunity in SWOT analysis of universities is the lack of high-level specialists in Latvia. As a threat, universities most often mentioned inadequate state financial support, as well as an inability to attract it from entrepreneurs.

Both in expert interviews and literature analysis, the main problem identified in cooperation between universities and entrepreneurs is the lack of a unified system for such cooperation; therefore, the authors have developed a model for cooperation and relationship building.

To apply the SADI model proposed by the authors, the university must first evaluate the current situation in cooperation with the entrepreneurs and which of the above activities are already being implemented. Further, university management can use a model to build a structure for cooperation with entrepreneurs, plan cooperation activities and monitor them, thus achieving closer relationships between them. Next, the most important strategical directions have to be evaluated and based on the available resources a choice in which of the levels - basic, medium or high - to work with entrepreneurs, and how much of the activities included in the SADI model should be implemented.

Further use of the model is adaptable to the capabilities and resources of each university (perhaps it is possible to assign part of the tasks to the existing staff (e.g., appoint responsible contact persons from departments, create a database, create a platform, etc.)). 


\section{References}

Bikse, V., Lusena-Ezera, I., Rivza, B., \& Volkova, T. (2016). The transformation of traditional universities into entrepreneurial universities to ensure sustainable higher education. Journal of Teacher Education for Sustainability, 18(2), 75-88. https://doi.org/10.1515/jtes-2016-0016

Caune, J., \& Dzedons, A. (2009). Stratēgiskē vadīšana (2 ${ }^{\text {nd }}$ ed.). Rīga: Lidojošā zivs (in Latvian).

Dubickis, M., Eliṇa, L., Gaile-Sarkane, E., Gūte, L., Ozoliňš, M., Paule, D., Rubina, L., Straujuma, A., Ščeulovs, D., \& Zeps, A. (2017). Projekta «Studiju procesa un industrijas sadarbības veicināšanas pasākumu alternatīivu model̦u izpēte» ārvalstu un Latvijas pieredzes analīze un datu apkopojums darbības programmas "Izaugsme un nodarbinātība» 1.1.1.3. pasākumam «Inovāciju granti studentiem». Izglīīibas un zinātnes ministrija. Retrieved from http://www.izm.gov.lv/images/ES_fondi/seminaru_DK/P\%C4\%93t\%C4\%ABjuma_rezult\%C4\%81ti_15.05.pdf(in Latvian).

Ekonomikas ministrija. (2016). Informatīvais ziṇojums par darba tirgus vidēja un ilgtermina prognozēm. Retrieved from https://www.em.gov.lv/files/tautsaimniecibas_attistiba/dsp/edited_EMZino_06_160616.pdf (in Latvian).

Fernández-López, S., Calvo, N., \& Rodeiro-Pazos, D. (2019). The funnel model of firms' R\&D cooperation with universities. Science and Public Policy, 46(1), 45-54. https://doi.org/10.1093/scipol/scy036

Hsieh, H. F., \& Shannon, S. E. (2005). Three approaches to qualitative content analysis. Qualitative Health Research, 15(9), 12771288. https://doi.org/10.1177/1049732305276687

Kozlinska, I. (2012). Obstacles to the university-industry cooperation in the domain of entrepreneurship. Journal of Business Management, 6, 153-160.

Latvijas sabiedriskie mēdiji. (2017). Kuras ir populārākās studiju programmas?. Retrieved from https://tv.lsm.lv/lv/raksts/31.07.2017-kuras-ir-popularakas-studiju-programmas.id103015 (in Latvian).

Martin, M. C., Moriuchi, E., Smith, R. M., Moeder, J. D., \& Nichols, C. (2015). The importance of university traditions and rituals in building alumni brand communities and loyalty. International Academy of Marketing Studies Journal, 19(3), 107-118.

Mascarenhas, C., Ferreira, J. J., \& Marques, C. (2018). University-industry cooperation: A systematic literature review and research agenda, Science and Public Policy, 45(5), 708-718. https://doi.org/10.1093/scipol/scy003

Mascarenhas, C., Marques, C. S., Galvão, A. R., \& Santos, G. (2017). Entrepreneurial university: Towards a better understanding of past trends and future directions. Journal of Enterprising Communities: People and Places in the Global Economy, 11, 316-338. https://doi.org/10.1108/JEC-02-2017-0019

Nielsen, C., \& Cappelen, K. (2014). Exploring the mechanisms of knowledge transfer in university-industry collaborations: A study of companies, students and researchers. Higher Education Quarterly, 68(4), 375-393. https://doi.org/10.1111/hequ.12035

Northam, J. (2012). Economic impact - UK universities contributed $£ 3.3 b n$ to the economy in 2010-11!. Bournemouth University. Retrieved from http://blogs.bournemouth.ac.uk/research/2012/08/01/economic-impact-uk-universities-contributed-3-3bn-tothe-economy-in-2010-11/

Ozols, N. (2018). 2017 gads darba tirgū noslēdzas ar nodarbinātības pieaugumu. Ekonomikas ministrija. Retrieved from https://www.em.gov.lv/lv/jaunumi/18242-2017-gads-darba-tirgu-nosledzas-ar-nodarbinatibas-pieaugumu (in Latvian).

Perkmann, M., \& Walsh, K. (2007). University-industry relationships and open innovation: Towards a research agenda. International Journal of Management Reviews, 9(4), 259-280. https://doi.org/10.1111/j.1468-2370.2007.00225.x

Rasmussen, E., \& Wright, M. (2015). How can universities facilitate academic spin-offs? An entrepreneurial competency perspective. The Journal of Technology Transfer, 40(5), 782-799. https://doi.org/10.1007/s10961-014-9386-3

Sabiedriskās domas un tirgus izpētes centrs. (2012). Kvalitatīvās izpētes metodes. Retrieved from http://www.petijumi.lv/kvalitativas-izpetes-metodes/ (in Latvian).

Stal, E., Andreassi, T., \& Fujino, A. (2016). The role of university incubators in stimulating academic entrepreneurship. RAI Revista de Administração e Inovação, 3(2), 89-98. https://doi.org/10.1016/j.rai.2016.01.004

Stanford University. (n.d.). The Triple Helix concept. Retrieved from https://triplehelix.stanford.edu/3helix_concept

Zeps, A. (2016). Stratēgiskie risinājumi organizācijas ilgtspējīgai attīstībai un starptautiskai izcilī̄ai: promocijas darba kopsavilkums. Rīga: RTU izdevniecība (in Latvian). 


\section{Appendix}

Table 4. Activities of the model of forming relations between universities and entrepreneurs (source: created by authors)

\begin{tabular}{|c|c|}
\hline Activity & Description \\
\hline $\begin{array}{l}\text { Concluding } \\
\text { cooperation agree- } \\
\text { ment }\end{array}$ & $\begin{array}{l}\text { The university concludes with new partners cooperation agreements defining the duties and the rights of } \\
\text { each party and specifying possible cooperation fields, such as: } \\
\text { - regular and systematic involvement of the entrepreneur's representatives in the university study } \\
\text { process (guest lectures on themes within the study process, participation in improving study pro- } \\
\text { grams, visits to the enterprise, offering themes for diploma papers, etc.); } \\
\text { - regular and systematic providing places internship to students; } \\
\text { - granting scholarships to the best students in a specific area; } \\
\text { - granting other forms of support for projects; } \\
\text { - cooperation in research; } \\
\text { - priority rights to the knowledge generated by the university and technologies in a specific field, } \\
\text { and the like; } \\
\text { - rights of use of the university infrastructure and premises; } \\
\text { - participation of the enterprise representative in the counsellors' convention; } \\
\text { - involvement of the enterprise employees in the association of the university alumni; } \\
\text { - other. }\end{array}$ \\
\hline Raising funds & $\begin{array}{l}\text { Irregular, periodic financial support provided by enterprises for carrying out activities, projects of the } \\
\text { university according to advertisement, sponsoring and other agreements. }\end{array}$ \\
\hline Providing services & $\begin{array}{l}\text { Providing services by the university to the enterprise: } \\
\text { - contract works; } \\
\text { - contract researches; } \\
\text { - ideas for commerce; } \\
\text { - lectures for improving the employees' qualification; } \\
\text { - using infrastructure; } \\
\text { - other. }\end{array}$ \\
\hline $\begin{array}{l}\text { Appointing the } \\
\text { person in charge } \\
\text { (groups of per- } \\
\text { sons) }\end{array}$ & $\begin{array}{l}\text { The university administration appoints the person in charge (group of persons) who: } \\
\text { - has knowledge of all spheres of activity of the structural units of the university and cooperation } \\
\text { opportunities with entrepreneurs and regularly informs thereon both current and prospective part- } \\
\text { ners; } \\
\text { - creates and maintains a database on the history of cooperation; } \\
\text { - maintains regular communication with the current partners (regular information e-mails on the top- } \\
\text { ical events, etc.); } \\
\text { - creates and maintains the platform for cooperation with entrepreneurs on the university webpage; } \\
\text { - prepares information for media, informing public on the success stories and the performance of the } \\
\text { university on a regular basis. }\end{array}$ \\
\hline $\begin{array}{l}\text { Creating a data- } \\
\text { base }\end{array}$ & $\begin{array}{l}\text { The university creates a database on cooperation and the person in charge regularly updates the data on } \\
\text { cooperation partners, history of cooperation, results of cooperation, deadlines, until which the respective } \\
\text { activities should be performed in the relevant year, etc.). It is desirable that the system should be accessible } \\
\text { to any university employee (with limited access rights) and also to representatives of students' self-gov- } \\
\text { ernment. }\end{array}$ \\
\hline $\begin{array}{l}\text { Creating a plat- } \\
\text { form }\end{array}$ & $\begin{array}{l}\text { The university creates a separate platform on its website (section website) for cooperation with entrepre- } \\
\text { neurs, which describes all possibilities of cooperation and specifies contact information, regularly suggests } \\
\text { discussions on issues topical for the industry, publishes success stories, informs entrepreneurs on the new- } \\
\text { est research, discoveries, etc. }\end{array}$ \\
\hline Creating a fund & $\begin{array}{l}\text { The university creates a fund promoting the university development with social benefit status, which can } \\
\text { administer donations from entrepreneurs, making provision of support less costly and more convenient. } \\
\text { The fund can also acquire the rights to pay scholarships to students, which is also an attractive manner of } \\
\text { cooperation for entrepreneurs. }\end{array}$ \\
\hline $\begin{array}{l}\text { Analysis of the in- } \\
\text { dustry needs and } \\
\text { integration into } \\
\text { the offer }\end{array}$ & $\begin{array}{l}\text { The university analyzes the needs of the industry and enhances the available study programs, creates new } \\
\text { ones, inter-disciplinary programs, etc, to ensure preparation of specialists matching the market require- } \\
\text { ments. }\end{array}$ \\
\hline $\begin{array}{l}\text { Joint initiatives } \\
\text { and projects }\end{array}$ & $\begin{array}{l}\text { To solve problems topical for the industry, universities together with entrepreneurs set forth new initiatives } \\
\text { nationwide, elaborate joint projects, programs, etc. }\end{array}$ \\
\hline
\end{tabular}

